Józef Cezary Kałużny, Rzym w sercu, serce w Rzymie. Mecenat naukowy arcybiskupa Józefa Bilczewskiego w latach 1901-1923, [w:] Starożytność chrześcijańska. Materiały zebrane, red. Józef Cezary Kałużny, t. 4, Kraków 2016, s. 103-115.

DOI: http://dx.doi.org/10.15633/9788374385282.07

Józef Cezary Kałużny

UNIWERSYTET PAPIESKI JANA PAWŁA II W KRAKOWIE

\title{
Rzym w sercu, serce w Rzymie. Mecenat naukowy arcybiskupa Józefa Bilczewskiego w latach 1901-1923
}

Wraz z objęciem w 1901 roku stolicy arcybiskupiej we Lwowie działalność naukowa Józefa Bilczewskiego - odpowiedzialnego i nieprzerwanie od tej pory zatroskanego o powierzony mu lud Boży pasterza - musiała ustąpić pierwszeństwa potrzebom archidiecezji lwowskiej. Czy praca naukowa, która stanowiła podstawową treść bez mała dwóch dekad jego życia, mogła ot tak zostać odłożona ad acta? Z tym pytaniem autor pragnie się zmierzyć w niniejszym rozważaniu, pisząc z jednej strony o fascynacji św. Józefa Bilczewskiego Rzymem, a z drugiej o świadomym, popartym własnym doświadczeniem mecenacie naukowym.

W tym miejscu trzeba zaznaczyć, że działalność naukowa ks. Józefa Bilczewskiego z lat 1885-190o przypadła na czas, w którym świat nauk historycznych i teologicznych ze szczególną uwagą przyglądał się początkom Kościoła. Przyczyniło się do tego wiele czynników tak natury naukowej, jak konfesyjnej. Z jednej bowiem strony był to okres gorących polemik pomiędzy katolikami a protestantami w kontekście ogłoszonego na soborze watykańskim I dogmatu o nieomylności papieża, z drugiej strony - wraz z odkryciem katakumb światło dzienne ujrzały tysiące nowych zabytków z okresu wczesnego chrześcijaństwa. Jak nietrudno się domyślić, każda ze stron próbowała wykorzystać te nowe „argumenty” źródłowe w niezwykle żywej i ostrej dyskusji, stąd determinant konfesyjny był częstokroć istotniejszy od kontekstu historycznego źródeł. Na szczęście dla ks. Józefa Bilczewskiego, w czasie gdy studiował on teologię na Uniwersytecie Gregoriańskim 
(1886-1888), pracami nad tzw. „podziemnym Rzymem” kierował Giovanni Battista de Rossi, zasłużenie nazywany „księciem rzymskich katakumb”. De Rossi zwracał baczną uwagę na to, aby uwolnić źródła katakumbowe od determinantu konfesyjnego, wprowadził krytykę tych źródeł, a z archeologii chrześcijańskiej uczynił samodzielną dyscyplinę naukową. Archeolog ten nie tylko zainteresował młodego teologa pamiątkami chrześcijańskiej przeszłości, ale i został jego mistrzem. Można śmiało powiedzieć, że dzięki de Rossiemu krytycznie analizowane pomniki katakumbowe stały się równoprawnymi źródłami przeszłości chrześcijańskiej, które rzucały nowe światło w studiach polskiego badacza nad dogmatami Kościoła.

Ksiądz Józef Bilczewski o swoim zetknięciu z materialnym dziedzictwem przeszłości Kościoła, a także z samym de Rossim, pisał tak:

Obok uczęszczania na wykłady nasunęła mi się od pierwszej mej wycieczki do katakumb praca nowa, której od grudnia r. 1886 poświęcam dziennie godzin kilka. Jest to studium monumentów katakumbowych [...]. Od pierwszej chwili ujrzałem, że katakumby są nie tylko miastem umarłych i sanctuarium pierwotnej sztuki chrześcijańskiej, ale i biblioteką, której pisane, rzeźbione i malowane autentyczne pierwszych czasów dokumenty rzucają światło na życie hierarchią i rząd pierwotnego Kościoła i zawiera lapidarną tradycję naszej wiary a w niej i z nią znaczną liczbę naszych dogmatów [...]. Zachęta ze strony mistrza i twórcy tego studium [de Rossiego]. Dał [on] łaskawie wskazówki i obiecał nie skąpić dalszych [...]. Po tych wskazówkach robiłem wycieczki do katakumb pod przewodnictwem dzielnego ucznia Komand[ora] De Rossiego, Ks. Józefa Wilperta ${ }^{1}$.

Pasja wkładana w badania nad antykiem chrześcijańskim, który topograficznie częstokroć zawężał się do zabytków ukochanego Rzymu, towarzyszyła od tego momentu ks. Józefowi Bilczewskiemu niemal na każdym etapie jego teologicznych badań. Zaś dwie wymienione wyżej osoby: de Rossi i ks. Wilpert, stały mu się szczególnie bliskie i bez przesady można powiedzieć, że wytyczyły nową linię prowadzonych przezeń badań naukowych².

1 Archiwum Uniwersytetu Jagiellońskiego, Pismo ks. Józefa Bilczewskiego do Rady Wydziału Teologicznego uj, sprawozdanie z wyjazdu na studia specjalistyczne do Rzymu i Paryża, Rzym 17.03.1888, sygn. wT II 14.

2 Szerzej na ten temat patrz: J. C. Kałużny, Święty Józef Bilczewski badacz starożytności chrześcijańskiej i jego interdyscyplinarna metoda $w$ świetle nieznanych materiałów źródłowych $z$ lat 1885-1900, Lwów-Kraków 2015, s. 51nn. 
Odtąd ks. Józef Bilczewski nosił w sobie pragnienie badania dziejów kształtowania się wiary Kościoła pierwotnego, wyrażające się w jego studiach nad dogmatami wiary. Prowadził swoje badania, poszukując tzw. miejsc teologicznych nie tylko w tekstach ojców Kościoła, ale także - stawiając je na równi z pierwszymi - w pomnikach przeszłości chrześcijańskiej. Źródłami w jego badaniach były zatem tak pisma wczesnochrześcijańskich pisarzy, jak i wszelkie inne świadectwa życia naznaczone konfesyjnością pierwszych chrześcijan. W związku z tym, przeglądając prace naukowe Józefa Bilczewskiego, na czele z dwoma monumentalnymi dziełami: Archeologia chrześcijańska wobec historyi Kościoła i dogmatu (Kraków 189o) oraz Eucharystia $w$ świetle najdawniejszych pomników piśmiennych, ikonograficznych, epigraficznych (Kraków 1898), łatwo zauważyć, że jego interdyscyplinarny, teologiczno-archeologiczny warsztat naukowy przesycony był zachwytem nad spójnością wszystkich rodzajów analizowanych i zestawianych przezeń źródeł . W roku 1901 rektor Uniwersytetu Lwowskiego ks. Józef Bilczewski, badacz dogmatów wiary, promotor archeologii chrześcijańskiej w Galicji, a nawet szerzej: na ziemiach Polski rozbiorowej, został wybrany na stolicę arcybiskupią Lwowa. Młody, zaledwie czterdziestoletni profesor, któremu nie było jeszcze dane zarazić naukową pasją żadnego adepta, musiał mieć świadomość zarzucenia nie tylko swoich badań, ale i nurtu badawczego, którego był promotorem. Właśnie w takim kontekście warto przyjrzeć się naukowemu mecenatowi arcybiskupa Józefa Bilczewskiego.

Przyglądając się z tej perspektywy dwudziestu latom arcypasterskiej posługi Józefa Bilczewskiego, można zauważyć, że pomimo rozlicznych obowiązków związanych z pełnioną funkcją nadal prowadził on działalność naukową. Nadał jej jednakowoż inny charakter, z formy „,czynnej” przechodząc w „bierną” - mecenat. Nie prowadził już badań osobiście, za to usilnie wspierał pracę naukową innych. Zawieszenie własnych badań nie oznaczało bynajmniej, że zaprzestał korzystania z posiadanej wiedzy - zdecydowanie wykorzystywał ją w pracy administracyjno-duszpasterskiej. Wczytując się w jego pisma pasterskie, odkryć można ten sam zapał i konsekwencję w dążeniu do prawdy o ukochanym Kościele, które towarzyszyły mu jako badaczowi antyku. Dzięki umiejętności wielopłaszczyznowego przedstawiania zagadnień teologiczno-pasterskich swoje listy pasterskie, odezwy i kazania zanurzał w teologii i osadzał w tradycji Kościoła, a zarazem czynił niezwykle przystępnymi i zrozumiałymi dla ludu. Zwrócił na to uwagę kardynał

3 J. C. Kałużny, Święty Józef Bilczewski, dz. cyt., s. 117nn, 169nn. 
Marian Jaworski, jeden z jego następców na stolicy arcybiskupiej Lwowa, we wprowadzeniu do współczesnego wydania pism pasterskich świętego:

[...] jego listy pasterskie na najważniejsze tematy naszej wiary i nauki Kościoła, jak: „O Najświętszym Sakramencie, O czci Najświętszej Maryi Panny” (kilka listów), „O Kościele Chrystusowym”, „Cześć Najświętszego Serca Jezusowego, Święty Józef Patron Kościoła Powszechnego”, „O małżeństwie, Sumienie, Charakter" - to sui generis traktaty teologiczne, które wprowadzały wiernych w pogłębione rozumienie tego, $\mathrm{w}$ co wierzą ${ }^{4}$.

Jakże znajome wydają się zagadnienia poruszane w pismach pasterskich Józefa Bilczewskiego, który roztropnie korzystał z przestudiowanych zagadnień i wydobywał z nich to, co w posłudze arcybiskupiej było mu potrzebne! Wybrzmiewają tu wiodące tematy jego badań naukowych, choć oczywiście podczas tworzenia owych pism przyświecały arcybiskupowi inne cele.

Jedyną publikację naukową tamtego czasu stanowią Obrazy eucharystyczne w katakumbach rzymskich. Referat na Kongresie Eucharystycznym $w$ Wiedniu $z 14$ ilustracjami $w$ tekście. Ta licząca dwadzieścia cztery strony książeczka, opublikowana we Lwowie w 1913 roku, stanowiła pokłosie odczytu wygłoszonego przez abp. Józefa Bilczewskiego 13 maja 1912 roku na Kongresie Eucharystycznym ${ }^{5}$. Cały materiał, uzupełniony jedynie o aktualniejsze wyniki badań dotyczących odkryć katakumbowych, arcybiskup oparł jednak na wcześniejszym swoim opracowaniu, Eucharystii. Promowana przezeń w archidiecezji adoracja Chrystusa obecnego w Eucharystii i zachwyt Najświętszym Sakramentem wydają się wypływać także z doświadczeń kapłana-naukowca. Naukowca, który zetknął się z głęboką wiarą Kościoła pierwszych wieków i jego czcią dla ofiary mszy świętej odkrywaną w ostatnim okresie pracy naukowej, a gruntownie przeanalizowaną właśnie we wspomnianym wyżej dziele o Eucharystii.

Wypełniającą wcześniejsze okresy życia ks. Józefa Bilczewskiego pracę naukowo-badawczą zastąpiła praca teologa-pasterza. Inne cele, inne środki używane do ich realizacji, to samo uniwersalne postrzeganie rzeczywistości Kościoła wczoraj i dziś. Arcybiskup Lwowa, który od momentu konsekracji

\footnotetext{
4 J. Bilczewski, Listy pasterskie, odezwy, kazania i mowy okolicznościowe, Lwów-Kraków 2005, s. 6.

5 Tenże, Eucharystia jako ofiara. Mowa wygłoszona na XXIII Kongresie Eucharystycznym w Wiedniu dnia 13 IX 1912 r., Poznań 1913.
} 
niemal zupełnie zarzucił własną pracę naukowca, nie zapomniał jednak o wartości badań naukowych. Spełniły się słowa ks. prof. Władysława Chotkowskiego, który w liście z 13 października 1900 roku pisał:

Co prawda wolałbym, żebyś, Magnifice, został przy książkach no - ale - jako Arcybiskup potrafisz popchnąć innych do nauki, a to przecież bardzo wiele warto, bo braknie nam bardzo ludzi .

I rzeczywiście, choć od momentu objęcia stolicy arcybiskupiej Józef Bilczewski wycofał się z czynnej pracy naukowej, pośrednio na różne sposoby wpływał na kształt życia naukowego Galicji i Lodomerii.

Pierwszą przestrzenią, w której przejawiało się jego zaangażowanie, było środowisko akademickie Lwowa, zwłaszcza Wydział Teologiczny Uniwersytetu Lwowskiego. Nowo mianowany arcybiskup doskonale zdawał sobie sprawę, jak istotne było, by diecezja posiadała światłych i wykształconych kapłanów. Aby to umożliwić, należało zadbać o wysoki poziom kadry naukowej Wydziału Teologicznego; abp Józef Bilczewski nie szczędził zatem środków na zagraniczne studia dla rokujących nadzieje kleryków i księży. Wielu z nich kończyło studia teologiczne w Innsbrucku, zaś specjalistyczne w Rzymie. Studenci ci zyskiwali nie tylko dogłębną wiedzę, ale również szeroki, pogłębiony obraz Kościoła powszechnego.

Dwudziestu kapłanów promowanych przez świętego arcybiskupa powróciło do diecezji z tytułami doktorów zagranicznych uczelni. Zachowana w Archiwum im. Arcybiskupa Baziaka w Krakowie korespondencja, którą metropolita prowadził ze swoimi podopiecznymi, zaświadcza o tym, że nie tylko interesował się ich rozwojem naukowym i właściwą formacją, ale i troszczył się o ich codzienne potrzeby. Owa wrażliwość na losy studentów wypływała z własnego bogatego doświadczenia. Czas studiów był dla niego niezwykle cennym okresem nie tylko z punktu widzenia naukowego, ale i w perspektywie dojrzewania w kapłaństwie i umiłowaniu Kościoła. Jego wspomnienia z Rzymu publikowane w „Gazecie Kościelnej” zawierają wiele głębokich, osobistych refleksjił.

${ }^{6}$ Archiwum im. Arcybiskupa Eugeniusza Baziaka (od 2012 roku znaczna część Archiwum im. Arcybiskupa Baziaka [dalej: ABK] znajduje się w depozycie Archiwum Uniwersytetu Jana Pawła II w Krakowie, tworząc samodzielną kolekcję), List ks. Władysława Chotkowskiego do ks. Józefa Bilczewskiego, Kraków 13.10.19oo, b. sygn. Całość tekstu patrz: J. C. Kałużny, Święty Józef Bilczewski, dz. cyt., Aneks 6, A4, s. 292.

7 J. Bilczewski, Z Rzymu, „Gazeta Kościelna” 2 (1894) nr 50, s. 487-488. 
Czy posiadając nowe możliwości, a zarazem szerokie znajomości w środowisku badaczy antyku, nie szukał okazji, by zarazić pasją do archeologii chrześcijańskiej któregoś ze swoich niedawnych słuchaczy i skierować go na odpowiednie studia? Zwłaszcza gdy wziąć pod uwagę propozycję, jaka pojawiła się w jednym z pierwszych listów ks. Józefa Wilperta kierowanych do Józefa Bilczewskiego arcybiskupa, datowanym na 3 grudnia 1901 roku:

Jeżeli Jego Ekscelencja Arcybiskup ma jakiegoś utalentowanego duchownego, który mówi w języku niemieckim, a jednocześnie ma zacięcie archeologiczne i ma być oddany na studia archeologiczne, to oczywiście osobiście jestem gotowy przyjąć go na kurs i pomagać we wszystkim ${ }^{8}$.

Już wcześniej pojawił się w Rzymie uczeń jeszcze lwowskiego profesora, który podjął studia archeologiczne. Był to ks. Tadeusz Olejniczak CR ${ }^{9}$. Jego list do ks. prof. Józefa Bilczewskiego z 20 czerwca 1900 roku nie pozostawia wątpliwości, co stanowiło centrum jego badań: „studia archeologiczne przerwałem na kilka dni w maju z powodu pielgrzymek polskich, które przeważnie po katakumbach oprowadzałem. Teraz znów wracam do Damazego" ${ }^{10}$.

${ }^{8}$ ABK, List ks. Józefa Wilperta do abpa Józefa Bilczewskiego, Rzym 3.12.1901, b. sygn.; J. C. Kałużny, Święty Józef Bilczewski, dz. cyt., aneks 1, tabela 1, W-B12, s. 214. Fragmenty listów ks. J. Wilperta do abpa J. Bilczewskiego tłumaczenie własne z j. niemieckiego.

9 Tadeusz Olejniczak CR (1877-1933) - W 1893 roku wstąpił do zgromadzenia zmartwychwstańców, w 1899 roku przyjął święcenia kapłańskie w Rzymie. W latach 1899-1903 był wicerektorem Kolegium Polskiego, w tym czasie uzyskał doktorat $\mathrm{z}$ archeologii chrześcijańskiej (J. Iwicki, Charyzmaty Zmartwychwstańców. Historia Zgromadzenia Zmartwychwstania Pańskiego, t. 2, Kraków-Kielce 2007, s. 178, przypis 77). Działalność naukowa ks. Olejniczaka koncentrowała się wówczas na archeologii chrześcijańskiej. W 1900 roku został sekretarzem sekcji dydaktycznej II Kongresu Archeologii Chrześcijańskiej w Rzymie, na którym zaprezentował dokonania dydaktyczno-naukowe polskiego środowiska naukowego w zakresie archeologii chrześcijańskiej. Jego wystąpienie uwzględniało w zasadzie wyłącznie działalność Bilczewskiego („Olejniczak, membro del Congresso archeologico e segretario della sezione didattica; tiene ai congressisti un discorso in lingua francese, sugli studi d'Archeologia Sacra in Polonia”. Annali dei Resurrezionisti, Anno I - 1900, Roma 1900, s. 74). W owym czasie napisał sprawozdanie $\mathrm{z}$ wręczenia kapelusza kardynalskiego biskupowi krakowskiemu Janowi Puzynie, który na kościół tytularny otrzymał wczesnochrześcijańską bazylikę św. Witalisa. To wydarzenie stało się niejako pretekstem do poświęcenia zasadniczej części artykułu antycznych korzeniach tego kościoła tytularnego. T. Olejniczak, Wręczenie kapelusza kardynalskiego księciu-kardynałowi Puzynie, „Roczniki Kolegium Polskiego w Rzymie" 2 (1902) nr 2, s. 95-116.

${ }^{10}$ ABK, List ks. T. Olejniczaka do ks. J. Bilczewskiego, Rzym 8.06.19oo, b. sygn.; J. C. Kałużny, Święty Józef Bilczewski, dz. cyt., Aneks 6, A2, s. 291-292. 
Po ukończeniu studiów i uzyskaniu doktoratu z archeologii chrześcijańskiej, w 1903 roku ks. Olejniczak powrócił do Lwowa. W roku 1906 został zatrudniony na Uniwersytecie Lwowskim, gdzie pracował przez sześć kolejnych lat. W sylabusach uniwersyteckich brakuje jednak informacji dotyczących tego, czy prowadził kurs archeologii lub sztuki wczesnochrześcijańskiej; wiadomo natomiast, że wykładał język włoski. Po przyjeździe z Rzymu z nieznanych powodów porzucił archeologię chrześcijańską na rzecz filozofii, z której się doktoryzował. W 1914 roku został w kościelnym środowisku oskarżony o sprzyjanie modernizmowi. Początkowo arcybiskup bronił go; gdy sytuacja stała się napięta, poprosił zmartwychwstańca o przeniesienie się na pewien czas do Rzymu. Ksiądz Olejniczak spędził w Wiecznym Mieście (z niewielką przerwą ${ }^{11}$ ) dziewiętnaście lat, aż do śmierci w 1933 roku; archeologia nie powróciła jednakże do głównego nurtu jego zainteresowań ${ }^{12}$.

Ksiądz Władysław Żyła (1877-1925) był kolejnym znanym dzisiaj studentem, którego abp Józef Bilczewski posłał na studia z zakresu sztuki kościelnej z uwzględnieniem archeologii chrześcijańskiej. Najpierw skierował go na studia teologiczne do Rzymu i Innsbrucku (1900-1902), które młody kapłan zwieńczył doktoratem z teologii. Zainteresowanie ks. Żyły historią sztuki kościelnej przerodziło się z czasem w prawdziwą pasję, która zaowocowała nie tylko podróżami naukowymi ${ }^{13}$, ale również regularnymi studiami nad historią sztuki chrześcijańskiej, estetyką i archeologią. Odbył je w Paryżu i Monachium w roku akademickim 1912/1913 $3^{14}$. Młody naukowiec otrzymał pełne poparcie swojego arcybiskupa dla działalności naukowej w zakresie historii sztuki kościelnej ${ }^{15}$. W latach 1913-1917 pracował na Wydziale

${ }^{11}$ Ks. Tadeusz Olejniczak powrócił do Lwowa pod koniec I wojny światowej, pełniąc w latach 1918-1920 posługę kapelana żołnierzy polskich.

${ }^{12}$ Od 1920 roku już na stałe przebywał w Rzymie, pełniąc różne odpowiedzialne funkcje w swoim zgromadzeniu. Pod koniec życia - w latach 1929-1933 - był rektorem Kolegium Polskiego.

${ }^{13}$ W teczce personalnej ks. Władysława Żyły znajduje się wiele listów kierowanych do abp. Bilczewskiego, w których nadawca zdaje sprawozdanie ze swoich podróży naukowych i studiów prowadzonych w zakresie historii sztuki kościelnej w Austrii (1911), Włoszech (1912), Francji (1912), Niemczech (1913), Portugalii (1913) i znów we Francji (1913). Patrz: A BK, Teczka personalna ks. Władysława Żyły, Listy ks. W. Żyły do abp. J. Bilczewskiego z lat 1911-1913, b. sygn.

${ }^{14}$ ABK, Teczka personalna ks. Władysława Żyły, List ks. W. Żyły do abp. J. Bilczewskiego, Paryż 27.02.1913, b. sygn.; List ks. W. Żyły do abp. J. Bilczewskiego, Monachium 12.05.1913, b. sygn.

${ }^{15}$ Abp Józef Bilczewski, przebywając w marcu 1913 roku w Wiedniu, odnotował: „byłem w minist[erstwie] oświaty; ministra nie było; u Ćwikl[ińskiego] omówiliśmy sprawę 
Teologicznym Uniwersytetu Lwowskiego jako adiunkt, w 1916 roku uzyskał tytuł doktora filozofii z zakresu historii sztuki i archeologii klasycznej na Wydziale Filozoficznym, a 30 lipca 1917 roku habilitował się na Wydziale Teologicznym tejże uczelni, prezentując rozprawę Kościół oo. Dominikanów $w$ Tarnopolu (1749-1779) ${ }^{16}$.

Po licznych staraniach w październiku 1919 roku ks. Władysław Żyła otrzymał ministerialną nominację na profesora nadzwyczajnego nowo powołanej przy Wydziale Teologicznym Uniwersytetu Jana Kazimierza Katedry Historii Sztuki Kościelnej z Uwzględnieniem Archeologii Chrześcijańskiej ${ }^{17}$. Badania, które prowadził, koncentrowały się na historii sztuki kościelnej jako takiej ze szczególnym uwzględnieniem historii sztuki lwowskich zabytków sakralnych oraz konserwacji zabytków, co świetnie ilustrują jego publikacje ${ }^{18}$ oraz działalność dydaktyczna na uniwersytecie. Archeologia chrześcijańska stała się jedynie dodatkiem w postaci cyklu kursowych wykładów z zakresu sztuki kościelnej ${ }^{19}$, choć dwukrotnie wystąpiła jako wykład samodzielny ${ }^{20}$, co dawało pewne nadzieje na zainicjowanie badań w tej dziedzinie, jeśli nie przez samego ks. Żyłę, to przez jego następców.

Nie dopisywało arcybiskupowi Józefowi Bilczewskiemu szczęście w promowaniu archeologii chrześcijańskiej w środowisku naukowym Uniwersytetu we Lwowie. Wybrani przezeń księża Tadeusz Olejniczak CR i Władysław Żyła nie do końca spełnili pokładane w nich nadzieje. Pierwszy z kapłanów definitywnie przeniósł centrum zainteresowań na inne dziedziny, a w końcu

reformy wyborczej, jest contra, tylko nie mówi tego głośno; poleciłem sprawę habilit[acji] x. Lisowskiego, petycję x. Żyły o subw[encję] na podróż nauk[ową]”. ABK, Dzienniczek Arcybiskupa Józefa Bilczewskiego, s. 261, b. sygn.

${ }^{16}$ J. Wołczański, Wydział Teologiczny Uniwersytetu Jana Kazimierza we Lwowie 1918-1939, Kraków 2002, s. 378.

17 Tamże.

${ }^{18}$ Spośród trzydziestu sześciu opublikowanych prac jedynie dwa artykuły poświęcił ks. Żyła badaniom nad antykiem chrześcijańskim: W. Żyła, O metodzie w historii sztuki starochrześcijańskiej, „Przegląd Polski” 38 (1920) t. 145/146, s. 106-119; tenże, Podróż na wschód, „Gazeta Kościelna” 20 (1912) nr 3, s. 24-25; nr 4, s. 39; nr 5, s. 41-43; A. Siwek, J. C. Kałużny, Działalność naukowa ks. Władysława Żyły na uniwersytecie we Lwowie. Zarys zagadnienia, [w:] Starożytność chrześcijańska. Materiały zebrane, t. 4, red. J. C. Kałużny, Kraków 2016, s. $151-161$.

${ }_{19}$ Wykład kursowy 1924/1925 (I-II) Historia sztuki kościelnej w zarysie. A. Siwek, J. C. Kałużny, Działalność naukowa ks. Władysława Żyły..., dz. cyt., aneks 1, s. 159-16o.

${ }^{20}$ Pierwszy, dwusemestralny (1923/1924) wykład wchodził w skład cyklu wykładów z tzw. sztuki ogólnej i nosił tytuł Sztuka starochrześcijańska i bizantyńska. Drugim był wygłoszony 3 marca 1924 roku wykład otwarty Bazylika starochrześcijańska. A. Siwek, J. C. Kałużny, Działalność naukowa ks. Władysława Żyły..., dz. cyt., aneks 1, tabela 3, s. 160. 
osiadł na stałe w Rzymie. Drugi uwzględniał w swojej działalności naukowo-dydaktycznej studium archeologii chrześcijańskiej, choć zasadniczo koncentrował się w swoich badaniach na historii sztuki nowożytnej. Istniała jednak szansa, że właśnie ks. Żyła zrealizuje plan upowszechnienia wiedzy na temat materialnego dziedzictwa Kościoła pierwotnego. Niestety, badacz zmarł w roku 1925, mając zaledwie czterdzieści osiem lat. Nie pozostawił uczniów, którzy podołaliby zadaniu podtrzymania jego rozległych badań nad sztuką kościelną; już w 1926 roku działalność Katedry Historii Sztuki Kościelnej z Uwzględnieniem Archeologii Chrześcijańskiej została zawieszona.

Inną formą popularyzacji archeologii chrześcijańskiej przez arcybiskupa Lwowa było utrzymywanie kontaktów ze środowiskiem badaczy antyku chrześcijańskiego i wspieranie ich swoim autorytetem, a kiedy było to możliwe, udzielanie pomocy materialnej. W tej perspektywie nie budzą zdziwienia kierowane do niego przez ks. Wilperta listy, w których wybitny badacz nie tylko zdawał sprawę ze swoich prac archeologicznych, ale i prosił o finansowe wsparcie druku kolejnej publikacji czy prowadzonych właśnie wykopalisk. Otrzymywał je od abp. Józefa Bilczewskiego wielokrotnie. Dla przykładu, rozpoczynając w 1903 roku kampanię wykopaliskową w katakumbie św. św. Marka i Marcelina, napisał do arcybiskupa:

Nakładem 20 tysięcy lirów mam nadzieję ukończyć tę pracę w trzy lata. Jedną trzecią kosztów przejmą Ojcowie trapiści od św. Kaliksta; pozostałe dwie trzecie muszę pokryć sam; tzn. z udziałem koniecznego wsparcia. Dlatego mam nadzieję, że Jego Wielmożna Ekscelencja Arcybiskup mógłby również z lekkością dorzucić grosik i go zaofiarować na poczet tegoż pięknego dzieła: tysiąc lirów w rozłożeniu na trzy lata. I w tej nadziei kończę ten list, załączając najserdeczniejsze życzenia ${ }^{21}$.

Że prośba ks. Wilperta nie pozostała bez echa, świadczy list tegoż z 1 listopada 1903 roku, w którym można przeczytać:

Serdecznie dziękuję za uprzejmą propozycję wsparcia moich wykopalisk u św. św. Marka i Marcelina. Mam nadzieję, że wiele uda mi się odkryć wła-

\footnotetext{
${ }^{21}$ ABK, List ks. J. Wilperta do abpa J. Bilczewskiego, Rzym 22.03.1903, b. sygn.; J. C. Kałużny, Święty Józef Bilczewski, dz. cyt., aneks 1, tabela 1, W-B14, s. 214.
} 
śnie w tym roku, ponieważ będziemy odkopywać bardzo ciekawą część; pozwolę sobie zdać z tego sprawozdanie Jego Ekscelencji Arcybiskupowi ${ }^{22}$.

Poza sprawą naukowego mecenatu istniała jeszcze kwestia Rzymu, miasta, w którym zrodziło się w polskim badaczu głębokie umiłowanie Kościoła wpisanego w historię człowieka wiary - także jego własną historię. Ten ślad zostawiały groby męczenników w rzymskich katakumbach, refleksje przed epitafiami schizmatyków, zaduma przy memoriach apostolskich czy w końcu cześć dla Stolicy Piotrowej i papieża, o czym bardzo często wspominał w swoich mowach już jako arcybiskup. Rzym wiązał się również z wieloma miłymi wspomnieniami czasu działalności naukowej, przyjaźni, znajomych miejsc. Wydaje się, że rozdzielanie czy wartościowanie tych rzymskich tęsknot Józefa Bilczewskiego byłoby błędem. Odwiedzając Rzym już jako arcybiskup, zawsze starał się spotkać się z ojcem świętym, o którym wyrażał się z niekłamaną miłością, następnie, poza obowiązkowymi spotkaniami związanymi z pełnioną funkcją, nigdy nie zaniedbywał nawiedzenia konfesji św. Piotra i św. Pawła. Pomimo napiętego grafiku podczas pobytu w Wiecznym Mieście, zawsze starał się wygospodarować kilka godzin na spotkania ze znajomymi naukowcami. W Dzienniczku pod datą 8 kwietnia 1913 roku czytamy:

Po południu byłem u x. Wilperta, pokazywał mi tablice do nowej swej pomnik[owej] publikacji O mozaikach i malow[idłach] starochrześ[cijańskich] jako dalszym ciągu sztuki katakumb[owej] $]^{23}$. Dałem mu 500 lirów na jego prace [...]. Potem przyszli znajomi prof. Kirsch z Fryburga ${ }^{24}$, Straniero ${ }^{25}$,

${ }^{22}$ A B K, List ks. J. Wilperta do abpa J. Bilczewskiego, Rzym 3.11.1903, b. sygn.; J. C. Kałużny, Święty Józef Bilczewski, aneks 1, tabela 1, W-B15, s. 214.

${ }^{23} \mathrm{~J}$. Wilpert, Die römischen Mosaiken und Malereien der kirchlichen Bauten vom IV.-XIII. Jahrhundert, Freiburg in Br. 1916.

${ }^{24}$ Ks. prof. Johan Peter Kirsch (1861-1941) - szwajcarski kapłan katolicki, studiował w Rzymie archeologię i sztukę wczesnochrześcijańską. Początkowo zajmował się badaniami katakumb, następnie rzymskimi tituli i bazylikami wczesnochrześcijańskimi. Przez długie lata profesor archeologii chrześcijańskiej we Fryburgu (1890-1932), a także organizator i pierwszy rektor Pontificio Instituto di Archeologia Cristiana w Rzymie (1925-1941). Zasłużony badacz materialnego dziedzictwa Kościoła pierwotnego, autor kilkudziesięciu prac z tej dziedziny. S. Heid, Johann Peter Kirsch, [w:] Personenlexikon zur Christlichen Archäologie. Forscher und Persönlichkeiten vom 16. bis zum 21. Jahrhundert, t. 1, Hrsg. S. Heid, M. Dennert, Regensburg 2012, s. 732-735.

${ }^{25} \mathrm{~W}$ położonym nieopodal Lateranu domu ks. Germana Straniera, kanonika laterańskiego, wynajął mieszkanie ks. Wilpert, gdy w 1891 roku wyprowadził się z Campo Santo 
Baumgarten $^{26}$, Ehses $^{27}$. Przyjemnie spędziłem wśród nich kilka godzin [...]. Prof. Kirsch opowiadał szczegóły, jak Ojciec św. napisał własnor[ęcznie] długi list do księcia Maksa w sprawie jego artyk[ułu] ${ }^{28}$.

Łatwo zauważyć, że czas odpoczynku i miłych rozmyślań nad rzeczami minionymi łączył się z głęboką świadomością tego, że prace prowadzone przez zaprzyjaźnionych badaczy są Kościołowi bardzo potrzebne.

Choć Rzym znajdował się tak daleko od Lwowa, oczywistą koniecznością było dla arcybiskupa podtrzymywanie żywych więzi między Stolicą Apostolską a oddaloną od serca świata katolickiego archidiecezją lwowską obrządku łacińskiego, funkcjonującą w rzeczywistości Kościoła wschodniego: pośród obrządków greckokatolickiego, ormiańskiego, w końcu prawosławnego. Powodowała Józefem Bilczewskim jednak także potrzeba serca: Rzym nieustannie go zachwycał, w mieście tym wciąż na nowo odkrywał ożywczą więź z tradycją Kościoła. Jako pasterz bardzo chciał dzielić się tym doświadczeniem ze swoimi podopiecznymi. Liczne pielgrzymki do Rzymu, w których brał udział i których często był pomysłodawcą, przygotowywane były tak, aby każdy uczestnik mógł doświadczyć duchowego zanurzenia w żywej tradycji Kościoła. Powróciwszy do Lwowa po pielgrzymce odbytej

Teutonico. Zamieszkiwał tam do wybuchu I wojny światowej. J. Rostropowicz, Muza nie da umrzeć mężowi godnemu chwaty. O Śląskim badaczu katakumb Jozefie Wilpercie 18571944, Opole 2004, s. 58.

${ }^{26}$ Ks. prof. Paul Maria Baumgarten (1860-1948) - katolicki prawnik i historyk Kościoła, dyplomata watykański. Przez szereg lat studiował dokumentację zgromadzoną w bibliotekach i archiwach watykańskich. Rezultaty prowadzonych przezeń badań zawarte są w licznych publikacjach, w których omawiał kwestie powstawania, kształtowania się i funkcjonowania Kurii Rzymskiej i dyplomacji watykańskiej w okresie średniowiecza (patrz m.in.: P.M. Baumgarten, Untersuchungen und Urkunden über die Camera Collegii Cardinalium für die Zeit von 1295 bis 1437, Leipzig 1898; tenże, Der Papst, die Regierung und die Verwaltung der Heiligen Kirche in Rom mit einer ausführlichen Lebensbeschreibung Papst Pius X, München 1904; tenże, Von der apostolischen Kanzlei. Untersuchungen über die päpstlichen Tabellionen und die Vizekanzler der Heiligen Römischen Kirche im XIII., XIV. und XV. Jahrhundert, Köln 1908). S. Heid, Paul Maria Baumgarten, [w:] Personenlexikon zur Christlichen Archäologie..., dz. cyt., s. 135-137; I.-M. Betz, Paul Maria Baumgarten - Deutscher Kirchenhistoriker und römischer Prister. Eine Annäherung an Leben und Werk, [w:] Studien zur Kirchengeschichte, t. 14, Hamburg 2013.

${ }^{27}$ Ks. prof. Stephan Ehses (1855-1926) - katolicki teolog i historyk Kościoła na stałe związany z Rzymem, długoletni dyrektor Römische Institut der Görres-Gesellschaft (1895-1926), zajmował się badaniami nad historią Kościoła xvi i xviı wieku. R. Haaß, Ehses Stephan, [w:] Neue Deutsche Biographie, t. 4, Berlin 1959, s. 366.

${ }^{28}$ ABK, Dzienniczek Arcybiskupa Józefa Bilczewskiego, s. 268-269, b. sygn. 
w 1902 roku, napisał list pasterski do duchowieństwa i wiernych, w którym czytamy między innymi:

Szczęście to ogromne być w Wiecznym Mieście. Nigdzie umysł i serce człowieka wierzącego nie znajduje tyle dla siebie pokarmu, tyle czystej rozkoszy duchowej, ile na tej ziemi przesiąkniętej krwią męczeńską Książąt Apostolskich i pierwszych chrześcijan. A jednak, mimo wszystkich nagromadzonych tamże grobów świętych, skarbów wiedzy i sztuki, dusza wyrywała się co dzień do kraju, do mojej diecezji, gdzie zostawiłem skarby nie mniejsze, bo dzieci moje duchowe, nad którymi Bóg pasterzem i ojcem mnie postawił [...]. Ale nie będę dłużej mówił o tym, co czuło i pragnęło serce moje dla Was [...], chcę raczej w krótkości opowiedzieć Wam, po co byłem w Rzymie, jakie i ja, i nasi pielgrzymi znaleźli tam przyjęcie, i co Wam od Ojca Świętego przywiozłem $^{29}$.

Po tym wprowadzeniu arcybiskup przeszedł do meritum, informując, o co zabiegał u papieża Leona xı dla diecezji i do czego się wobec papieża w imieniu diecezjan zobowiązał:

Prosiłem tedy Ojca Świętego, aby mnie raczył przyjąć na osobnym posłuchaniu, bo potrzebuję w ważnych sprawach jego oświecenia i rady, pragnę zwierzyć się przed Nim i z tego, co cieszy w zarządzaniu owczarnią, i z tego, co smuci i boli. Najpierw [...] oświadczając, że [...] składamy wszyscy, duchowni i świeccy, wyznanie wiary katolickiej, hołd naszego przywiązania do Stolicy św. i niezłomnej ku niej wierności, zapewnienie, że chcemy kochać Ojca Świętego lepiej niż wszystkie inne narody [...]. Mówiłem mu o tym, jak to lud nasz spragniony jest kościółka i kapłana w swej wiosce, jak duchowieństwo i wierni składają ofiary na budowę kaplic i na utrzymanie Małego Seminarium, dalej, że znaczna część wiernych zaraz na pierwsze moje wezwanie pospieszyła z pomocą kapłanom w nauczaniu katechizmu naszej dziatwy drogiej, i że wielka jest nadzieja, iż przyjmie się i zapuści głęboko korzenie w całej diecezji ważne i zbawienne dzieło adoracji i płynące z niego naśladowanie cnót Boskiego Serca Jezusowego w Najświętszym Sakramencie. Prawda, Najdrożsi moi, prawda, że wszyscy dochowacie święcie przyrzeczenia, które wasz pasterz w imieniu Waszym złożył Zastępcy Boga na ziemi? ${ }^{30}$

\footnotetext{
${ }^{29}$ J. Bilczewski, Listy pasterskie..., t. 1, dz. cyt., s. 81 .

${ }^{30}$ Tamże, s. 83.
} 
Z listów pasterskich i odezw arcybiskupa Józefa Bilczewskiego, w których pobrzmiewają echa kolejnych pielgrzymek do Rzymu, przebija miłość do Wiecznego Miasta, Stolicy Piotrowej, „ziemi przesiąkniętej krwią męczeńską Książąt Apostolskich i pierwszych chrześcijan”, do „grobów świętych, skarbów wiedzy i sztuki” ${ }^{2}$. Umiejętność wykorzystania owej miłości w służbie archidiecezji lwowskiej stanowiła niezwykły dar. Tym, co jako młody kapłan odkrywał w Rzymie podczas studiów nad teologią i archeologią chrześcijańską, pragnął dzielić się z ludem jako jego pasterz. Można śmiało powiedzieć, że Rzym na zawsze pozostał w sercu świętego Józefa Bilczewskiego, zaś jego serce w jakimś stopniu pozostało w Rzymie. Wydarzeniem, które w widzialny sposób przypieczętowało więź świętego arcybiskupa z Wiecznym Miastem, było umieszczenie mozaiki z jego przedstawieniem w kaplicy Matki Bożej Częstochowskiej, znajdującej się w kryptach watykańskich pod bazyliką św. Piotra ${ }^{33}$.

${ }^{31}$ Tamże, s. 81.

${ }^{32}$ Tamże.

${ }^{33}$ Podczas uroczystości konsekracji biskupiej arcybiskupa koadiutora lwowskiego Mieczysława Mokrzyckiego, przy okazji wizyty ad limina biskupów Ukrainy obrządku łacińskiego 29 września 2007 roku, po wcześniejszym uzgodnieniu ze Stolicą Apostolską dokonano odsłonięcia mozaiki przedstawiającej św. abp. Bilczewskiego, którą umieszczono w położonej w podziemiach bazyliki św. Piotra kaplicy Matki Bożej Częstochowskiej. 